Egyptian Journal of Aquatic Biology \& Fisheries

Zoology Department, Faculty of Science,

Ain Shams University, Cairo, Egypt.

ISSN $1110-6131$

Vol. 24(5): 467 - 482 (2020)

www.ejabf.journals.ekb.eg

\title{
Pathological, bacteriological and seasonal prevalence of Aeromonas hydrophila, vibrio vulnificus, Proteus vulgaris and Pseudomonas aeruginosa; infecting Oreochromis niloticus in some Egyptian fish farms
}

\author{
Islam Elgohary ${ }^{1}$, Jehan I. Abd Elatief ${ }^{2}$, Nasser G. Fadel ${ }^{1}$, Alaa E. Eissa ${ }^{3}$ and \\ Mahmoud A. Mahmoud ${ }^{*}$
}

1. Department of Pathology, Animal Health Research Institute, Dokki, ARC, Giza, 12619, Egypt

2. Fish Diseases Department, Animal Health Research institute, Dokki, ARC, Giza, 12619. Egypt

3. Department of Aquatic Animal Medicine and Management, Faculty of Veterinary Medicine, Cairo University, Giza 12211, Egypt

4. Department of Pathology, Faculty of Veterinary Medicine, Cairo University, Giza 12211,

Egypt

"Corresponding Author: mahmoudaly@cu.edu.eg

\begin{abstract}
ARTICLE INFO
Article History:

Received: July 20, 2020

Accepted: Aug. 17, 2020

Online: Aug. 20, 2020

Keywords:

Pathology;

A. hydrophila;

V. vulnificus;

P. vulgaris;

P.aeruginosa;

O. niloticus

\section{ABSTRACT}

In this study, ninety fish samples showing clinical signs of septicemia were collected from two private fish farms of Oreochromis niloticus; forty fish were sampled from fayoum and fifty were from sharkia governorte, Egypt, during four seasons (autumn 2018 to summer 2019). The sampled diseased fish represented $10 \%$ of the fish, showing clinical signs and the mortality rate along the year was $15 \%$. In postmortem examination, the signs of septicemia on the affected fishes were clear in the most of the internal organs. The histopathological results were fully described in different organs of the affected fish. Bacteriological examination revealed isolation of Aeromonas hydrophila with prevalence rate along the year $77.33 \%$ with the highest prevalence in summer (100\%) in El Fayoum and it was $29.72 \%$ along the year with the highest prevalence in autumn $33.33 \%$ in El Sharkia governorate. Vibrio vulnificans in El Fayoum governorate was not isolated but it was isolated from El Sharkia with prevalence rate of $16.22 \%$; with the highest prevalence in autumn $(33.33 \%$,). Proteus vulgaris was identified in both governorates with overall prevalence rate of $6.67 \%$ in El Fayoum and the highest prevalence was recorded in both autumn and spring seasons $(11.11 \%)$. In El Sharkia it was $27.03 \%$ but with the highest prevalence in summer (100\%). Pseudomonas aeruginosa was also recorded with the prevalence rate of 20\% along the year in El Fayoum governorate with the highest prevalence in winter $55.56 \%$ and it was $27.03 \%$ in El Sharkia governorate with the highest prevalence in winter $43.75 \%$. In antibiotic sensitivity testing, each microorganism showed resistance against erythromycin except Vibrio vulnificus that showed sensitivity. Aeromonas hydrophila and Proteus vulgaris showed resistance to colistin sulphate and susceptibility to sulpha-trimethoprime. Vibrio vulnificus and Pseudomonas aeruginosa showed resistance against sulpha-trimethoprime and sensitive against colistin sulphate.
\end{abstract}




\section{INTRODUCTION}

In Egypt, fish production is representing $20 \%$ of white animal protein production. The most common cultured fish is Oreochromis niloticus. (Younes et al., 2015). Bacterial diseases are most important causative agent causing high mortality and great economic losses in aquaculture (Scarpellini et al., 2004). Aeromonas hydrophila, Vibrio vulnificus, Proteus vulgaris and Pseudomonas aeruginosa are Gram negative microorganisms causing general signs of septicemia with severe economic losses in aquacultures. Aeromonas hydrophila is the main cause of hemorrhagic septicemia in aquaculture system in Egypt and causing great economic losses (Alyahya et al., 2018). Motile aeromonas septicemia caused by Aeromonas hydrophila is a disease persisting to several weeks causing gradually mortality (Zhang $\boldsymbol{e t}$ al., 2016). Histopathologically, the lesions of the aeromonas infection are characterized by degenerative changes in kidneys, liver, spleen, gills and stomach (Dong et al., 2017; Hassan et al., 2017); Vibriosis is causing common postmortem lesions including skin depigmentation, hemorrhagic spots, congested liver, spleen and stomach; the disease usually cause economic losses and mortality (Younes et al., 2016). Proteus vulgaris was isolated from ulcers in the fresh water fish (Mandal et al., 2002) and the naturally infected fishes with Proteus vulgaris showed hemorrhages in buccal cavity, body surfaces and base of the fins, fin rot, protruded hemorrhagic anus, congested gills and internal organs together with focal hemorrhage on the surface of the liver (Aya, 2013). The naturally infected fishes with pseudomonas aeruginosa showing hemorrhage in body surfaces especially at base of the fins, fin rot, loose of scales, skin ulceration and distended abdomen; postmortem lesions are hemorrhagic ascetic fluid, enlarged pale liver, enlarged congested spleen and hemorrhagic enteritis (Magdy et al., 2014). The prevalence rates of infection with Aeromonas hydrophila, Vibrio vulnificus, Proteus vulgaris and Pseudomonas aeruginosa in fishes are greatly different and are multifactorial dependent; it may change from time to time even within the same fish species. The prevalence rates of infection with Aeromonas hydrophila was recorded by Ahmed (2002) as $47.3 \%$ in O.niloticus, and it was $14 \%$ as recorded by Ebeed et al., (2017). The prevalence rate of Vibrio vulnificus was $8 \%$ in fresh water fish (Saad et al., 2015) and 12.5\% in Cultured Oreochromis niloticus around Qarun Lake (Younes et al., 2016). In case of Proteus vulgaris, the prevalence rate was 12\% (Aya, 2013). and it was recorded as 2\% by Rabab et al., (2019); while in P.aeriginosa, the Prevalence rate of infection in O.niloticus during the period between 2015-2016 was $60 \%$ in winter and $24 \%$ in summer (Elham et al., 2017) while the prevalence rate of Pseudomonas spp. In O.niloticus Was $13.8 \%$ (Manal and Ahmed, 2016). Thus the need of updating information of the microbial prevalence in fish aquaculture is very important and could help in the diseases control at different locations.

The aim of this work was isolation and identification of the bacterial infection causing mortalities in some $O$. niloticus aquaculture at some locations in Egypt, recording the seasonal variation of the infection and studying the antibiotic sensitivity for these isolates. 


\section{MATERIALS AND METHODS}

This study has been approved by the Institutional Animal Care and Use Committee, Faculty of Veterinary Medicine, Cairo University, Egypt (Vet. CU. IACUC, approval No. Vet CU20022020164).

\section{Fish sampling}

Two private fish farms of Oreochromis niloticus at El Fayoum and El Sharkia governorates showed signs of septicemia with a history of recorded mortality ranged from 10-20\% in each farm during autumn 2018 to summer 2019. Ninety fish that weighted $80 \pm 5 \mathrm{~g}$ representing about $10 \%$ of fishes showing clinical signs were collected from the infected ponds that showing mortalities and/ or clinical signs. Alive fish were transferred in boxes supplied with aerators, while Moribund and freshly dead fish transported in icebox to wet laboratory unit of Fish Diseases Department; Animal Health Research Institute (AHRI), Dokki, Giza, Egypt. Lesions and postmortem findings of naturally infected fish were recorded according to (Conroy and Herman 1981; Austin and Austin, 2012). The specimens from each region were analyzed for both bacteriological and histopathological examination.

\section{Bacteriological examination}

Loopfuls aseptically taken from liver, kidney, spleen and brain according to (Austin and Austin, 2012) directly streaked on the different selective media as Thiosulfate-citratebile salt- Sucrose (TCBS) agar, Salmonella Shigella (SS) Agar, Medium Base (Oxoid, Ltd.), Pseudomonas Agar Base (LabM, UK) an XLD (Oxoid, Ltd), followed by incubation at $25^{\circ} \mathrm{C} / 24 \mathrm{hrs}$. Identification of pure bacterial isolates were identified by biochemical characterization following the criteria described in Bergey's Manual of Determinative Bacteriology (Holt et al., 1993) and performed by commercial API *20NE, API*20E kits (Bio-Merieux,France) following the criteria described by Elmer $\boldsymbol{e t}$ al., (1998). Pure colonies were transferred to glycerol broth $20 \%$ at $-80{ }^{\circ} \mathrm{C}$ (Pujalte, et al., 2003).

\section{Antibiotic sensitivity test}

Sensitivity was determined by the agar diffusion method Quinn, et al., ( 2002) using 6 $\mathrm{mm}$ diameter commercial discs (Oxoid) included the following antibiotics' discs. The antibiotic discs were Amoxicillin, Gentamicin, Nalidixic acid, Colistin suphate, erythromycin, nitrofurantoin, sulpha-trimethoprime, ciprofloxacin and Vibriostate O/129. Antibiotic sensitivity was tested on Mueller-Hinton agar with or without $3 \% \mathrm{NaCl}$. Inhibition zones diameters were interpreted as sensitive, intermediate and resistant according to CLSI (2010).

\section{Pathological examination}

\section{1. histopathological examination}

Tissue specimens from spleen, kidney, liver and brain of the same fishes used in bacteriological examination were immediately sampled and immersed in neutral buffer formalin $10 \%$. After proper fixation, the specimens were trimmed, washed, dehydrated in ascending grades of ethyl alcohol, then cleared in xylol and embedded in paraffin. Thin 
sections about 4-6 microns in thickness were prepared and stained with Haris haematoxylin and Eosin, gram's stain and prussion blue for microscopic examination (Bancroft and Marilyn, 2002). The tissue changes were described and photographed using research light microscope Olympus BX-53.

\subsection{Immunohistochemical evaluation:}

The immunohistochemistry for paraffin section was performed according to Zhang $\boldsymbol{e t}$ al., (2016). Briefly, rehydration of paraffin section by passing the sections in descending grades of alcohols (alcohol 100\%, 95\% for $5 \mathrm{~min}$. to each, $80 \%$, $70 \%$ for $3 \mathrm{~min}$. to each), antigen retrieval was occurred by immersion of tissue section in antigen retrieval buffer then placed in autoclave at $121{ }^{\circ} \mathrm{C}$ then leave the slides to cool down at room temperature, washing 3 times by PBS, removing of excess blocking buffer and incubate the section with primary antibodies in humid box at $4{ }^{\circ} \mathrm{C}$ for $12-16 \mathrm{hrs}$, KJand incubate at $25{ }^{\circ} \mathrm{C}$ for 1 hour, remove excess of secondary antibody and washing 3 times by PBS and finally adding adequate amount of counterstaining dye.

\section{RESULTS}

\section{Clinical and postmortem examination}

This research planned to investigate the main causes of mortalities in some O. niloticus farms. The lesions of naturally infected fishes of each strain were nearly the same, with evidence of septicemia. The infected fished showed abnormal swimming, gasping, off food, loss of scales, petechial hemorrhage on all body surfaces, loss of scales, congestion of the blood vessels on the surface of all body fins and gills (Figure 1A). In visceral organs, the postmortem examination of internal organ showed congested kidney, congested and enlarged spleen and marbled liver (Figure 1B).
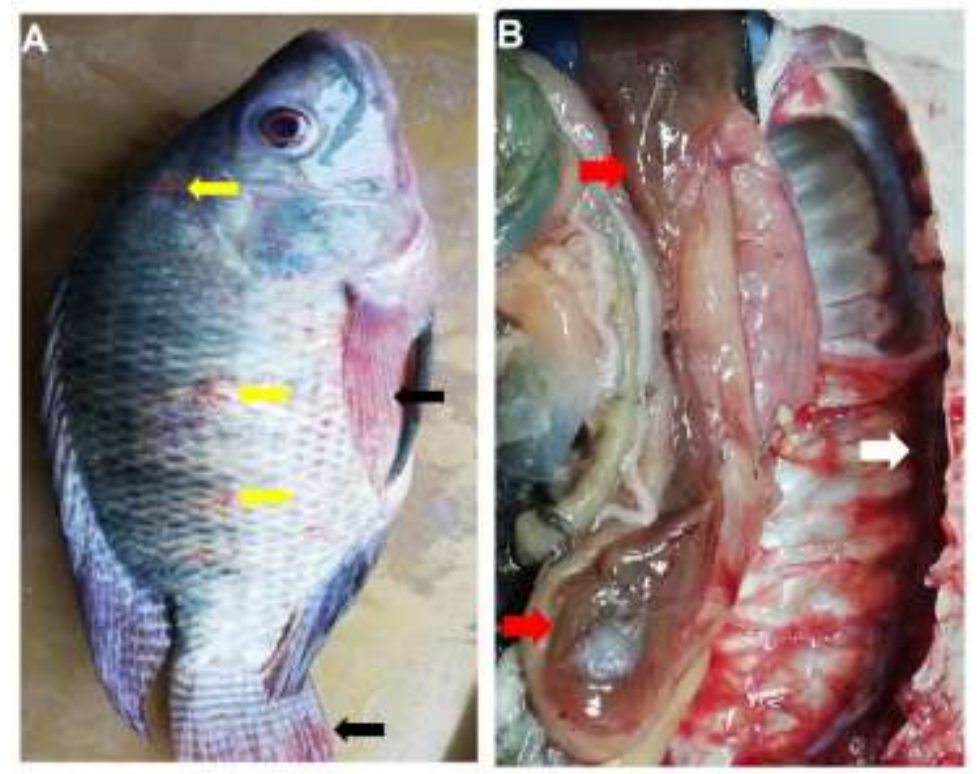

Fig.1 A) congestion in pectoral and tail fins (black arrows), loss of scales and presence of petechial hemorrhage on body surface (yellow arrows). B) congested kidney (white arrow) and marbled friable liver (red arrows). 


\section{Bacterial examination}

Bacteriological and morphological characterization of isolates from infected O. niloticus revealed that, A.hydrophila isolates appeared colorless colonies on SS agar, V.vulnificus gave yellow colonies on TCBS media, $P$. vulgaris isolates produced yellow colonies in XLD media and P.aeruginosa isolates were greenish colonies on Pseudomonas Agar Base. All isolates were Gram-negative, motile, rods shape wile V. vulnificus were slightly curved rods. The Phenotypic and Biochemical characterizations of all isolates of naturally infected $O$. niloticus are summarized in table $1 \& 2$.

Table 1: Phenotypic and Biochemical characterizations of A.hydrophila and V.vulnificus using API*20NE.

\begin{tabular}{|c|c|c|c|}
\hline \multicolumn{2}{|c|}{ Biochemical test } & A.hydrophila & V.vulnificus \\
\hline \multicolumn{2}{|c|}{ Colony characters onto TCBS medium } & Yellow colored colonies & Yellow colored colonies \\
\hline \multicolumn{2}{|c|}{ Colony characters onto SS } & Colorless & - \\
\hline NO3 & Potassium nitrate & - & + \\
\hline TRP & Trytophane production & - & + \\
\hline GLU & Glucose fermentaion & + & + \\
\hline ADH & Arginine Dihydrolase & + & - \\
\hline URE & Urease & - & - \\
\hline ESC & Esculin & + & + \\
\hline GEL & Gelatin & + & + \\
\hline PNG & $\begin{array}{c}\text { Para Nitrophenyl D } \\
\text { Galactopyranosidase B Glucosidase }\end{array}$ & + & + \\
\hline GLU & Glucose assimilation & + & - \\
\hline ARA & Arabinose assimilation & + & - \\
\hline MNE & Mannose assimilation & + & - \\
\hline MAN & Mannitol assimilation & + & - \\
\hline NAG & $\mathrm{N}$ acetyl Glucosamine assimilation & + & - \\
\hline MAL & Maltose assimilation & + & - \\
\hline GNT & Potassium GlucoNate aasimilation & + & - \\
\hline CAP & Capric acid assimilation & + & - \\
\hline LDI & Adipic acid assimilation & - & - \\
\hline MLT & Malate assimilation & + & - \\
\hline CIT & Tri sodium Citrate assimilation & - & - \\
\hline PAC & Phenyle acetic acid assimlation & - & - \\
\hline OX & Oxidase & + & + \\
\hline
\end{tabular}


Table2: Phenotypic and Biochemical characterizations of P. aeruginosa and Proteus vulgaris using API*20NE.

\section{Biochemical test \\ P. aeruginosa \\ Proteus vulgaris}

Colony characters onto Pseudomonas agar Greenish colonies base medium

\begin{tabular}{|c|c|c|c|}
\hline \multicolumn{2}{|c|}{ Colony characters onto XLD medium } & \multirow{2}{*}{$\begin{array}{l}- \\
-\end{array}$} & \multirow{2}{*}{$\begin{array}{c}\text { Yellow colonies } \\
-\end{array}$} \\
\hline ONPG & B-galactosidase & & \\
\hline ADH & Arginine Hydrolase & + & - \\
\hline LDH & Lysine Decarboxylase & - & - \\
\hline ODH & Ornithine Decarboxylase & - & - \\
\hline CIT & Citrate & + & + \\
\hline $\mathbf{H}_{2} \mathrm{~S}$ & $\mathrm{H}_{2} \mathrm{~S}$ production & - & + \\
\hline URE & Urease & $-1+$ & + \\
\hline TDA & Tryptophane Deaminase & - & + \\
\hline IND & Indole & - & + \\
\hline VP & Vagous Prescour & - & - \\
\hline GEL & Gelatinase & $+/-$ & $-/+$ \\
\hline GLU & Glucose & $+/-$ & + \\
\hline MAN & Mannitol & - & - \\
\hline INO & Inositol & - & - \\
\hline SOR & Sorbitol & - & - \\
\hline RHA & Rhaminose & - & - \\
\hline SAC & Sucrose & - & + \\
\hline MEL & Melobinose & - & - \\
\hline AMY & Amyldain & - & $-/+$ \\
\hline ARA & Arabinose & $-/+$ & - \\
\hline OX & Cytochrome Oxidase & + & - \\
\hline
\end{tabular}




\section{Seasonal and overall prevalence/year}

Aeromonas hydrophila prevalence rate was $77.33 \%$ in El Fayoum governorate during the year with the highest prevalence in summer season (100\%) and it was $29.72 \%$ in El Sharkia governorate with the highest prevalence in autumn season, 33.33\%; V. vulnificus prevalence rate in El Fayoum governorate during the year was zero \% and it was $16.22 \%$ in El Sharkia governorate with the highest prevalence in autumn season (33.33\%), P. vulgaris prevalence rate was $6.67 \%$ in El Fayoum governorate with the highest prevalence in both autumn and spring seasons, $11.11 \%$; and it was $27.03 \%$ in El Sharkia governorate with the highest prevalence in summer season $(100 \%)$; while Pseudomonas aeruginosa prevalence rate was $20 \%$ in El Fayoum governorate with the highest prevalence in winter season, $55.56 \%$; and it was $27.03 \%$ in El Sharkia governorate with the highest prevalence in winter season $(43.75 \%)$. The prevalence rate of the isolated bacteriafrom four organs of naturally infected fish, $O$. niloticus during the four seasons starting from autumn 2018 to summer 2019 was summarized in (table $3 \& 4$ ). 
Table 3: The prevalence rate of A. hydrophila and $V$. vulnificus isolated from four organs of naturally infected $O$. niloticus during the four seasons.

\begin{tabular}{|c|c|c|c|c|c|c|c|c|c|}
\hline \multirow{3}{*}{$\begin{array}{c}\text { Place } \\
\text { El } \\
\text { Fayoum }\end{array}$} & \multirow[t]{3}{*}{$\begin{array}{c}\text { Season } \\
\text { and year }\end{array}$} & \multicolumn{3}{|c|}{$\begin{array}{l}\text { No. of examined fish showing clinical } \\
\text { signs (90 fish representing } 10 \%)\end{array}$} & \multirow[t]{3}{*}{ Organ } & \multicolumn{2}{|c|}{ No. of isolates } & \multicolumn{2}{|c|}{ Prevalence rate \% } \\
\hline & & \multicolumn{2}{|c|}{ Isolated bacteria } & \multirow{2}{*}{$\begin{array}{c}\text { Negative for } \\
\text { gram + ve } \\
\text { bacteria }\end{array}$} & & \multirow{2}{*}{$\begin{array}{c}\text { A. } \\
\text { hydrophila }\end{array}$} & \multirow{2}{*}{$\begin{array}{c}V . \\
\text { vulnificus }\end{array}$} & \multirow{2}{*}{$\begin{array}{c}\text { A. } \\
\text { hydrophila }\end{array}$} & \multirow{2}{*}{$\begin{array}{c}\text { V. } \\
\text { vulnificus }\end{array}$} \\
\hline & & $\begin{array}{c}\text { A. } \\
\text { hydrophila }\end{array}$ & $\begin{array}{c}V . \\
\text { vulnificus }\end{array}$ & & & & & & \\
\hline & \multirow{4}{*}{$\begin{array}{l}\text { Autumn, } \\
2018\end{array}$} & \multirow[t]{4}{*}{4} & \multirow[t]{4}{*}{0} & \multirow[t]{4}{*}{4} & Brain & 0 & 0 & \multirow[t]{4}{*}{88.89} & \multirow[t]{4}{*}{0} \\
\hline & & & & & liver & 4 & 0 & & \\
\hline & & & & & kidney & 3 & 0 & & \\
\hline & & & & & spleen & 1 & 0 & & \\
\hline & \multirow{4}{*}{$\begin{array}{l}\text { Winter, } \\
2018\end{array}$} & \multirow[t]{4}{*}{4} & \multirow[t]{4}{*}{0} & \multirow[t]{4}{*}{1} & Brain & 0 & 0 & \multirow{4}{*}{44.44} & \multirow[t]{4}{*}{0} \\
\hline & & & & & liver & 2 & 0 & & \\
\hline & & & & & kidney & 1 & 0 & & \\
\hline & & & & & spleen & 1 & 0 & & \\
\hline & \multirow{4}{*}{$\begin{array}{c}\text { Spring, } \\
2019\end{array}$} & \multirow[t]{4}{*}{6} & 0 & 3 & Brain & 0 & 0 & 77.78 & 0 \\
\hline & & & & & liver & 2 & 0 & & \\
\hline & & & & & kidney & 3 & 0 & & \\
\hline & & & & & spleen & 2 & 0 & & \\
\hline & Summer, & 1 & 0 & 9 & Brain & 0 & 0 & 100 & 0 \\
\hline & 2019 & & & & liver & 1 & 0 & & \\
\hline & & & & & kidney & 1 & 0 & & \\
\hline & & & & & spleen & 1 & 0 & & \\
\hline $\begin{array}{r}T \\
(40 \text { exai }\end{array}$ & $\begin{array}{l}\text { tal } \\
\text { (ned fish) }\end{array}$ & 15 & 0 & 17 & Total & 22 & 0 & 73.33 & 0 \\
\hline El & Autumn, & 1 & 2 & 7 & Brain & 0 & 0 & 33.33 & 33.33 \\
\hline Sharkia & 2018 & & & & liver & 1 & 2 & & \\
\hline & & & & & kidney & 1 & 1 & & \\
\hline & & & & & spleen & 1 & 0 & & \\
\hline & Winter, & 2 & 1 & 4 & Brain & 0 & 0 & 31.25 & 6.25 \\
\hline & 2018 & & & & liver & 2 & 0 & & \\
\hline & & & & & kidney & 2 & 1 & & \\
\hline & & & & & spleen & 1 & 0 & & \\
\hline & Spring, & 1 & 1 & 8 & Brain & 0 & 0 & 30 & 20 \\
\hline & 2019 & & & & liver & 1 & 1 & & \\
\hline & & & & & kidney & 1 & 1 & & \\
\hline & & & & & spleen & 1 & 0 & & \\
\hline & Summer, & 0 & 0 & 12 & Brain & 0 & 0 & 0 & 0 \\
\hline & 2019 & & & & liver & 0 & 0 & & \\
\hline & & & & & kidney & 0 & 0 & & \\
\hline & & & & & spleen & 0 & 0 & & \\
\hline $\begin{array}{r}T \\
(50 \text { exaI }\end{array}$ & $\begin{array}{l}\text { tal } \\
\text { ined fish) }\end{array}$ & 4 & 4 & 31 & Total & 11 & 6 & 29.72 & 16.22 \\
\hline
\end{tabular}


Table 4: The prevalence rate of Proteus vulgaris and Pseudomonas aeruginosa isolated from four organs of naturally infected $O$. niloticus during the four seasons.

\begin{tabular}{|c|c|c|c|c|c|c|c|c|c|}
\hline \multirow[t]{3}{*}{ Place } & \multirow{3}{*}{$\begin{array}{l}\text { Season } \\
\text { and year }\end{array}$} & \multicolumn{3}{|c|}{$\begin{array}{l}\text { No. of examined fish showing clinical } \\
\text { signs ( } 90 \text { fish representing } 10 \%)\end{array}$} & \multirow{3}{*}{ Organ } & \multicolumn{2}{|c|}{ No. of isolates } & \multicolumn{2}{|c|}{ Prevalence rate \% } \\
\hline & & \multicolumn{2}{|c|}{ Isolated bacteria } & \multirow{2}{*}{$\begin{array}{c}\text { Negative for } \\
\text { gram +ve } \\
\text { bacteria }\end{array}$} & & \multirow{2}{*}{$\begin{array}{c}P . \\
\text { vulgaris }\end{array}$} & \multirow{2}{*}{$\begin{array}{c}P . \\
\text { aeruginosa }\end{array}$} & \multirow{2}{*}{$\begin{array}{c}P . \\
\text { vulgaris }\end{array}$} & \multirow{2}{*}{$\begin{array}{c}P . \\
\text { aeruginosa }\end{array}$} \\
\hline & & P. vulgaris & P. aeruginosa & & & & & & \\
\hline \multirow{16}{*}{ El Fayoum } & \multirow{4}{*}{$\begin{array}{l}\text { Autumn, } \\
2018\end{array}$} & \multirow{4}{*}{1} & \multirow{4}{*}{0} & \multirow{4}{*}{4} & Brain & 0 & 0 & \multirow{4}{*}{11.11} & \multirow{4}{*}{0} \\
\hline & & & & & liver & 1 & 0 & & \\
\hline & & & & & kidney & 0 & 0 & & \\
\hline & & & & & spleen & 0 & 0 & & \\
\hline & \multirow{4}{*}{$\begin{array}{l}\text { Winter, } \\
2018\end{array}$} & \multirow{4}{*}{0} & \multirow{4}{*}{5} & \multirow{4}{*}{1} & Brain & 0 & 0 & \multirow{4}{*}{0} & \multirow{4}{*}{55.56} \\
\hline & & & & & liver & 0 & 2 & & \\
\hline & & & & & kidney & 0 & 3 & & \\
\hline & & & & & spleen & 0 & 0 & & \\
\hline & \multirow{4}{*}{$\begin{array}{l}\text { Spring, } \\
2019\end{array}$} & & & & Brain & 0 & 0 & & \\
\hline & & & & & liver & 1 & 1 & & \\
\hline & & 1 & 1 & 3 & kidney & 0 & 0 & 11.11 & 11.11 \\
\hline & & & & & spleen & 0 & 0 & & \\
\hline & & & & & Brain & 0 & 0 & & \\
\hline & Summer, & & & & liver & 0 & 0 & & \\
\hline & 2019 & 0 & 0 & 9 & kidney & 0 & 0 & 0 & 0 \\
\hline & & & & & spleen & 0 & 0 & & \\
\hline $\begin{array}{r}\text { To } \\
(40 \text { exam }\end{array}$ & d fish) & 2 & 6 & 17 & Total & 2 & 6 & 6.67 & 20 \\
\hline & & & & & Brain & 0 & 0 & & \\
\hline & Autumn, & & 1 & 7 & liver & 1 & 1 & & \\
\hline & 2018 & 1 & 1 & 7 & kidney & 1 & 0 & 22.22 & 11.11 \\
\hline & & & & & spleen & 0 & 0 & & \\
\hline & & & & & Brain & 0 & 0 & & \\
\hline & Winter, & & & & liver & 2 & 3 & & \\
\hline & 2018 & 2 & 3 & 4 & kidney & 1 & 4 & 18.75 & 43.75 \\
\hline & & & & & spleen & 0 & 0 & & \\
\hline EI Sharkia & & & & & Brain & 0 & 0 & & \\
\hline & Spring, & 2 & 1 & 8 & liver & 1 & 1 & 30 & 20 \\
\hline & 2019 & 2 & 1 & 8 & kidney & 2 & 1 & 30 & 20 \\
\hline & & & & & spleen & 0 & 0 & & \\
\hline & & & & & Brain & 0 & 0 & & \\
\hline & Summer, & 1 & 0 & 12 & liver & 1 & 0 & 100 & 0 \\
\hline & 2019 & 1 & 0 & 12 & kidney & 1 & 0 & 100 & 0 \\
\hline & & & & & spleen & 0 & 0 & & \\
\hline $\begin{array}{r}\text { To } \\
(50 \text { exam }\end{array}$ & d fish) & 6 & 5 & 31 & Total & 10 & 10 & 27.03 & 27.03 \\
\hline
\end{tabular}

\section{Antibiotic sensitivity}

The antibiotic sensitivity test is demonstrated in table 5. 
Table 5: antibiotic sensitivity test for of $A$. hidrophila, $V$. vulnificus $P$. vulgaris, and $P$. aeruginosa isolated from four organs of naturally infected $O$. niloticus.

\begin{tabular}{|c|c|c|c|c|}
\hline Antibiotic Discs & A. hydrophila & V. vulnificus & P. vulgaris & P. aeruginosa \\
\hline Amoxicillin (20/10mcg) & $\mathrm{I}(12 \mathrm{~mm})$ & $\mathrm{S}(16 \mathrm{~mm})$ & $\mathrm{R}(0 \mathrm{~mm})$ & $\mathrm{R}(0 \mathrm{~mm})$ \\
\hline 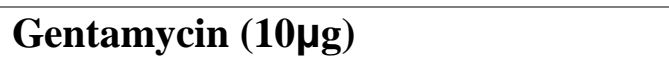 & $\mathrm{S}(16 \mathrm{~mm})$ & $\mathrm{I}(13 \mathrm{~mm})$ & $\mathrm{S}(16 \mathrm{~mm})$ & $\mathrm{I}(13 \mathrm{~mm})$ \\
\hline nalidixic acid (30mcg) & $\mathrm{S}(20 \mathrm{~mm})$ & $\mathrm{S}(20 \mathrm{~mm})$ & $\mathrm{I}(15 \mathrm{~mm})$ & $\mathrm{R}(0 \mathrm{~mm})$ \\
\hline colistin sulphate $(10 \mu g)$ & $\mathrm{R}(0 \mathrm{~mm})$ & $\mathrm{S}(11 \mathrm{~mm})$ & $\mathrm{R}(0 \mathrm{~mm})$ & $\mathrm{S}(12 \mathrm{~mm})$ \\
\hline Erythromycin $(15 \mu g)$ & $\mathrm{R}(0 \mathrm{~mm})$ & $\mathrm{S}(19 \mathrm{~mm})$ & $\mathrm{R}(0 \mathrm{~mm})$ & $\mathrm{R}(0 \mathrm{~mm})$ \\
\hline Nitrofurantoin $(300 \mu g)$ & $\mathrm{S}(18 \mathrm{~mm})$ & $\mathrm{S}(17 \mathrm{~mm})$ & $\mathrm{R}(0 \mathrm{~mm})$ & $\mathrm{R}(0 \mathrm{~mm})$ \\
\hline sulfamethxazol/trimethoprim $(25 \mu \mathrm{g})$ & $\mathrm{S}(17 \mathrm{~mm})$ & $\mathrm{R}(0 \mathrm{~mm})$ & $\mathrm{S}(16 \mathrm{~mm})$ & $\mathrm{R}(0 \mathrm{~mm})$ \\
\hline 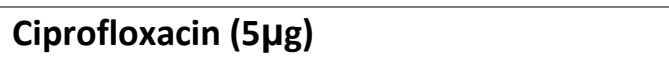 & $\mathrm{S}(21 \mathrm{~mm})$ & $\mathrm{S}(23 \mathrm{~mm})$ & I (16 mm) & $\mathrm{I}(16 \mathrm{~mm})$ \\
\hline $0 / 129(150 \mu \mathrm{g})$ & - & $\mathrm{S}$ & - & - \\
\hline
\end{tabular}

S: Sensitive R: Resistant I: Intermediate

\section{Pathological examination:}

5.1. Histopathological findings of naturally infected fishes in Fayoum governorate In histopathological examination, congestion of hepatoportal blood vessels in the liver with aggregation of eosinophilic granular cells, in addition to vacuolar degeneration in hepatocytes were commo (Fig. 2A\&B). The hemosiderin pigments were deposited between the hepatocytes which positively stained by Prussian blue (Fig. 2C). The lesion in some cases was advanced and the hepatopancreatic cells showed necrobiotic changes (Fig. 2D). Thickening in wall of splenic blood vessels, depletion of white pulp and deposition of melanin pigment around some splenic blood vessels were common findings in spleen (Fig. 2E\&F). In kidneys, hemorrhage was found between renal tubules with hemosiderin pigments deposition (Fig. 2G). Vacuolar degeneration in the renaltubular epithelium was also noticed together with interstitial hemorrhage and mononuclear inflammatory cells infiltration; some nuclei of the renal tubular epithelium showed pyknosis indicating necrobiotic changes in the epithelium.In such cases, deposition of melanin pigments between renal tubules and hypercelluarity in renal glomeruli were common(Fig. $2 \mathrm{H}$ ).

\subsection{Histopathological findings of naturally infected fishes in Sharkia governorate}

The liver showed congestion of hepatoportal blood vessels with necrosis in hepatocytes (Fig. 3A\&B), in addition to vacuolar degeneration in some hepatocytes (Fig. 3C). Some hepatocytes showed apoptosis and hemorrhage between hepatocytes (Fig. 3D). The apoptotic bodies were positively stained by caspase 3 immunohistochemistry (Fig. 3E). Some cases showed aggregation of bacteria in the areas of necrosis; The lesion in such cases surrounded with many inflammatory cells (Fig. 3F). In spleen, lymphocytic depilation in white pulp of with melanin pigment deposition and subcapsular splenic 
necrosis were common (Fig. 3G). the renal tissue showed hypercelluarity in renal glomeruli and some nuclei of renal tubular epithelium showed necrobiotic changes (Fig. $3 \mathrm{H})$.

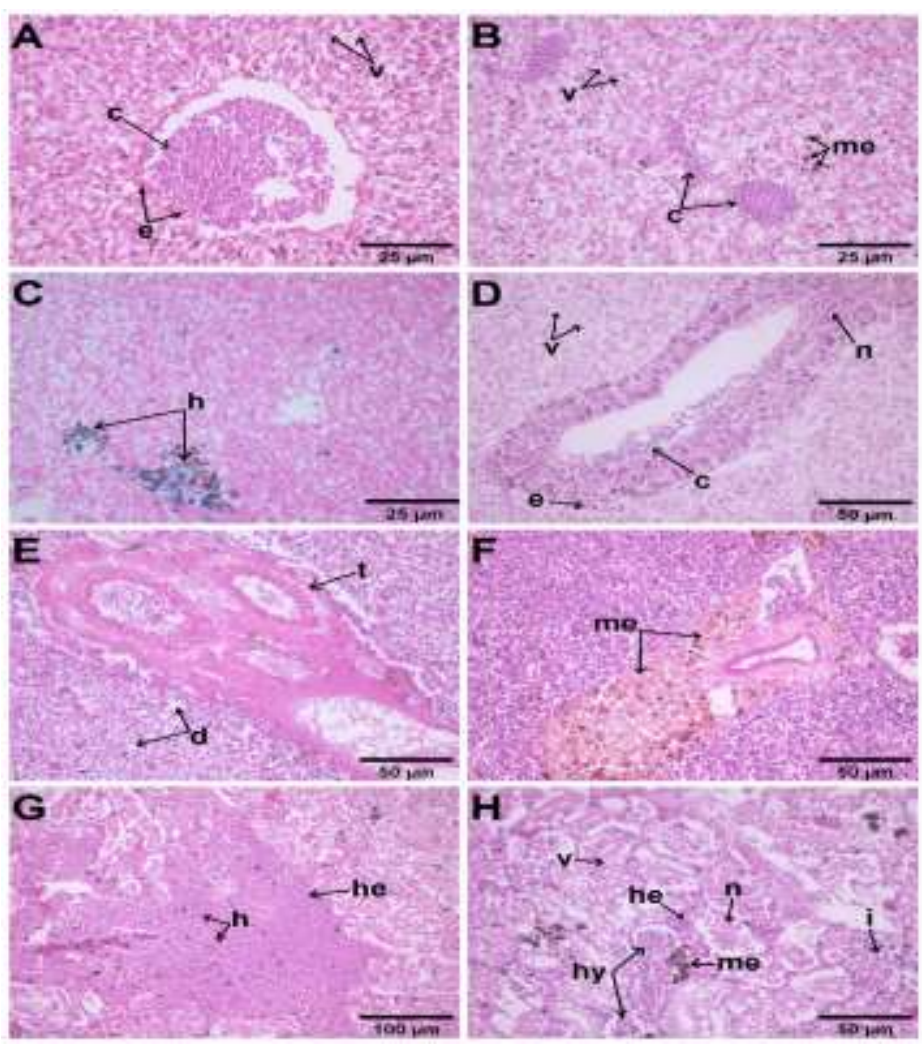

Fig.2: Histopathological sections of Oreochromis niloticus naturally infected with Gram negative bacteria collected from El Fayoum governorate showing; A) Congestion of hepatoportal blood vessels (c) surrounded by eosinophilic granular cells (e) and some hepatocytes showing vacuolar degeneration (v). B) hepatocytes showing vacuolar degeneration (v), congestion of hepatoportal blood vessels (c) with melanin pigment deposition between hepatocytes (me). C) Deposition of hemosiderin pigment (h) in the tissue of liver which stained positive, appear blue color, by Prussian blue. D) Necrosis in hepatopancreatic cells (n), congestion of hepatopancreatic blood vessels (c) surround by eosinophilic granular cells (e), in addition to vacuolar degeneration in hepatocytes (v). E) Thickening in wall of blood vessels of spleen ( $t$ ) in addition to depletion of white pulp (d). F) melanin pigment deposition (me) around blood vessels of spleen. G) Hemorrhage (he) between renal tubules with hemosiderin deposition (h). H) Hemorrhage (he) and mononuclear cells infiltration (i) between renal tubules together with necrotic changes (n) in the epithelium, in addition to vacuolar degeneration in epithelium of renal tubules (v) and deposition of melanin pigment (me) between the renal tubules; the glomeruli showed hypercellularity (hy). 


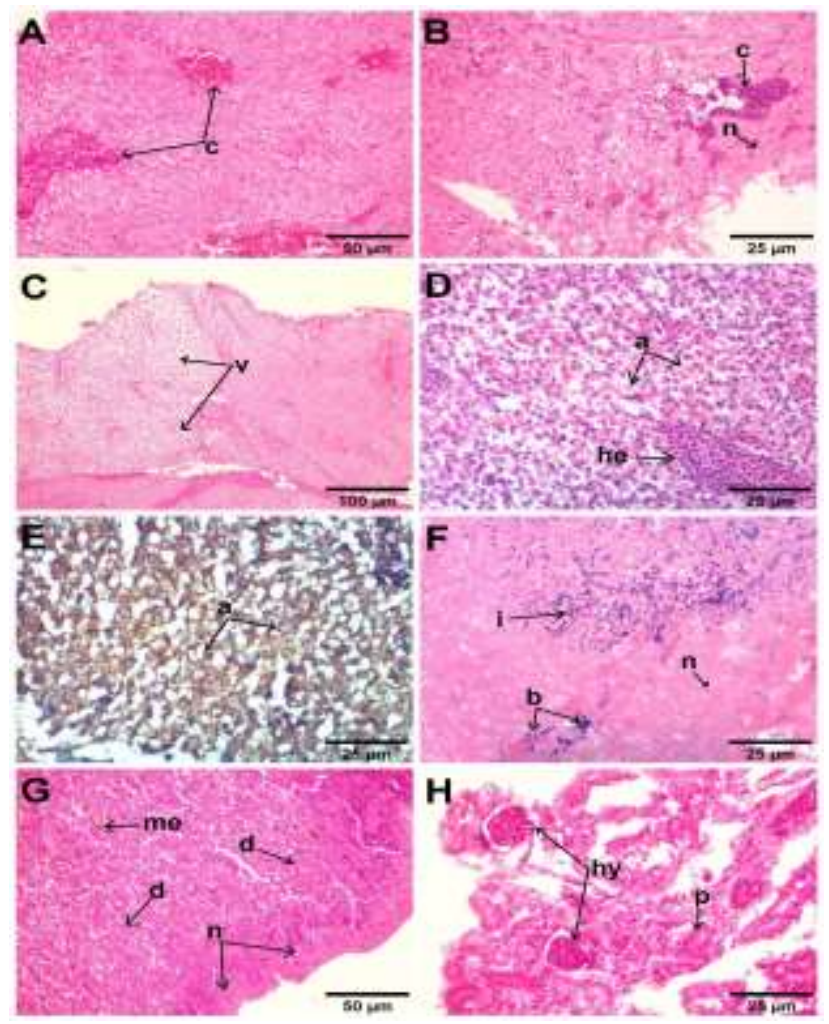

Fig. 3: Histopathological sections of Oreochromis niloticus naturally infected with Gram negative bacteria collected from El Sharkia governorate showing; A) congestion of hepatoportal blood vessels (c). B) Congestion of hepatoportal blood vessels (c) and some hepatocytes showing necrotic changes (n). C) Some hepatocytes showing vacuolar degeneration (v). D) Some hepatocytes showing apoptosis with formation of apoptotic bodies (a), in addition to hemorrhage (he) between hepatocytes. E) Apoptotic hepatocytes (a) positively stained by caspase 3 immunohistochemistry. F) Hepatocytes showing necrotic changes ( $n$ ) with mononuclear inflammatory cells aggregation (i), in addition to presence of bacteria (b) between hepatocytes. G) Deplation (d) in white pulp with melanin pigment (me) deposition, in addition to subcapsular splenic necrosis (n). H) renal glomeruli showing hypercellularity (hy) and some nuclei of renal tubule epithelium showing pyknosis (p) with necrobiotic changes in the epithelium.

\section{DISCUSSION}

In regard to the results of clinical signs and postmortem lesions in naturally infected $O$. niloticus, the lesions in the examined tissues were correlated to the four microorganisms where these microorganisms were isolated from the same examined tissues. The lesions in infected fishes in two governorates were the same which externally including loss of scales, petechial hemorrhage on lateral part of the body with congestion of blood vessels in all body fins and internally including congested kidney, enlarged congested spleen and marbled liver. Our findings were nearly similar to external signs found by (Ahmed, 2002; Aya, 2013; Magdy et al., 2014; Sumithra et al., 2019). 
Bacterial diseases affecting O.niloticus considered one the most important problems causing severe economic losses. In our study, the prevalence rate of A.hydrophila during the sampling period in El fayoum governorate was $73.33 \%$ and in El sharkia governorate was $29.72 \%$. These finding showed variation with the finding of Ahmed (2002) who recorded that the prevalence rate of A. hydrophila was $47.3 \%$ and Ebeed et al., (2017) who recorded that the prevalence rate of $A$. hydrophila was $14 \%$. The prevalence rate of $V$. vulnificus in El fayoum governorate was $0 \%$ and in El sharkia governorate was $16.22 \%$ which showed variation with the finding of Younes et al., (2016) who recorded that the prevalence rate of $V$. vulnificus was $12.5 \%$ and Hemmat et al., (2018) who recorded that the prevalence rate of $V$. vulnificus was $4 \%$. The prevalence rate of $P$. vulgaris in El fayoum governorate was $6.67 \%$ and in El sharkia was $27.03 \%$ which disagreed with Aya (2013) who recorded that prevalence rate of $P$. vulgaris was $12 \%$. The prevalence rate of P. aeruginosa in El fayoum governorate was $20 \%$ and in El sharkia governorate was $27.03 \%$ which is disagreed with Eissa et al., (2010) who recorded that the prevalence rate of Pseudomonas species was 30.83\%.

From a bacteriological point of view, the the dominant isolates were from liver, kidney and spleen who agreed with (Ahmed, 2002; Eissa et al., 2010; Aya, 2013; Sumithra $\boldsymbol{e}$ t al., 2019), who isolated the A. hydrophila, V. vulnificus, $P$. vulgaris and $P$. aeruginosa respectively from the same three organs. The biochemical characters of Aeromonas hydrophila were similar to findings of Ahmed (2002) who isolated Aeromonas hydrophila from cultured tilapia. Also the biochemical characters of $V$. vulnificus were agreed with finding of Younes et al., (2016) who isolated V. vulnificus Strains from Cultured O. niloticus around Qarun Lake, Egypt. Proteus vulgaris ferment sucrose which disagreed with Aya (2013) who isolated Proteus vulgaris from Nile tilapia which not ferment sucrose while the biochemical characters of Pseudomonas aeruginosa similar to findings of Eissa et al., (2010) who Isolated Pseudomonas aeruginosa from Tilapia in Qaroun and Wadi-El-Rayan Lakes, Egypt.

In our study, Aeromonas hydrophila showed sensitivity to Nalidixic acid, Gentamicin and Sulfa-trimethoprime and resistant to erythromycin which is partially agreed with Wamala et al., (2018) who found that Aeromonas hydrophila showed sensitivity to Nalidixic acid, Gentamicin and Sulfa-trimethoprime and intermediate resistance to erythromycin. $V$. vulnificus showed intermediate resistance to gentamicin, resistance Sulfa trimethoprime, sensitive to Nalidixic acid, colistin sulphate and ciprofloxacin which not similar to finding of Sumithra et al., (2019) who showed that V. vulnificus resistant to colistin sulphate and sensitive to gentamicin, Sulfa trimethoprime, Nalidixic acid and ciprofloxacin. P. aeruginosa showed intermediate resistance to gentamicin, resistant to erythromycin and Sulfa-trimethoprime, Amoxycillin and Nalidixic which disagreed with Eissa et al., (2010) who showed that highly sensitive to Gentamicin, Erythromycin, and Sulfa trimethoprime. In addition, showed resistance to Amoxycillin and Nalidixic acid. The histopathological findings in our results including vacuolar degeneration in hepatocytes, congestion in hepatoportal blood vessels and hepatopancreatic blood vessels with melanin and hemosiderin pigments deposition between hepatocytes and necrosis in hepatopancreatic cells and hepatocytes were partially disagreed with (Ahmed, 2002 ; Aya, 2013) and agreed with (Magdy et al., 2014 ; Sumithra et al., 2019) in vacuolar degeneration and congestion of portal blood vessels. Thickening in the wall of splenic blood vessels, melanin deposition around splenic blood vessels, necrosis in subcapsular 
splenic tissue with depletion of white pulp were partially agreed with Magdy et al., (2014) who recorded depletion of white pulp together with deposition of melanin pigments and disagreed with the findings of Sumithra et al., (2019) who mention that presence of hemosiderin pigments in splenic tissue are most common. The lesions in the kidneys including hemorrhages and mononuclear inflammatory cells aggregation between the renal tubules, deposition of melanin and hemosiderin pigments, hypercelluarity in renal glomeruli, vacuolar degeneration and necrotic changes in the epithelial lining of renal tubule could be attributed to the deieterious effect of the secreted enzymes by the isolated bacteria. In this regard, many authors have been attributed the lesions of such bacterial infection to the secretion of some bacterial enzymes; Metalloprotease enzyme which is one of protease enzymes secreted by Vibrio vulnificus and causing cutaneous tissues damages, hemorrhage and edema (Jones and Oliver, 2009), exotoxin A secreted by $P$. aeruginosa has been incriminated as a cause of local tissue damage and tissue invasion (Iglewski et al., 1977). Hemolysins are another group of the virulence factors which are multifunction enzymes secreted by A.hydrophila, inducing multiple effects including hemolytic, cytotonic, and cytotoxic activities (Erova et al., 2012).

\section{CONCLUSION}

A. hydrophila, $P$. vulgaris, $V$. vulnificus and $P$. aeruginosa caused disease problems in some fish farms at El Fayoum and El Sharkia governorates, the diseases have seasonal variation in such locations and so, prophylactic measures against such bacteria should be considered to avoid the outbreaks in the highest prevalence seasons of the infection; Development of vaccination protocol against the locally isolated bacteria is very important as a prophylactic measure in Egyptian fish farms especially in El Fayoum and El Sharkia regions. This study could be used as a model to demonstrate and screen the bacterial infection in different seasons in other locations.

\section{REFERENCES}

Ahmed M.M. El-Ashram, (2002). On Aeromonas hydrophila infection among cultured tilapias: a biological, histopathological and management study. Egypt. J. Aquat. BioL \& Fish., 6 (3): 181-202.

Alyahya, S.A.; Ameen, F. ; Al-Niaeem, K. S. ; Al-Sa'adi, B. A.; Hadi S. and Mostafa, A. A. (2018). Histopathological Studies of Experimental Aeromonas Hydrophila Infection in Blue Tilapia, Oreochromis Aureus. Saudi Journal of Biological Sciences., 25(1): 182-185.

Austin, B. and Austin, A.D. (2012). Bacterial fish pathogens: diseases of farmed and wild fish. 5th ed. Chichester, UK.

Aya, G. S. (2013). Susceptibility rate of nile tilapia, (Oreochromis niloticus) and red swamp crayfish, (Procambarus clarkii) to proteus vulgaris infection. . Assiut Vet. Med.J., 59(138):138-145.

Bancroft, J.D. and Marilyn, A. (2002). Theory and practice of histological techniques. $5^{\text {th }}$ ed. London, Edinburgh, New York, Philadelphia, St.Louis, Sydney and Toronto. 
CLSI, (2010). Performance Standards for Antimicrobial Susceptibility Testing, 20th Informational Supplement. Clinical and Laboratory Standards Institute, M100-S20 \& M100-S-20-U

Conroy, D.A. and Herman, L.R.(1981) Textbook of fish diseases. West Sylvania: T. F. H. Dong, H.T.; Techatanakitarnan, C.; Jindakittikul, P.; Thaiprayoon, A.; Taengphu, S.; Charoensapsri, W.; Khunrae, P.; Rattanarojpong, T. and Senapin, S. (2017). Aeromonas jandaei and Aeromonas veronii caused disease and mortality in Nile tilapia, Oreochromis niloticus (L.). J. Fish Dis., 40(10):1395-1403.

Ebeed, A. Saleh; Alaa Eldin, M.A. Morshdy; A.M. Mohamed and Basma, F. Elsobary, (2017). Prevalence of Aeromonas Species and Their Herbal Control in Fish. Global Veterinaria., 18 (4): 286-293.

Eissa, N.M.E.; Abou El-Ghiet, E.N.; Shaheen, A.A. and Abbass, A. (2010). Characterization of Pseudomonas Species Isolated from Tilapia "Oreochromis niloticus" in Qaroun and Wadi-El-Rayan Lakes, Egypt. Global Veterinaria., 5 (2): 116-121.

Elbana, T.A.; Bakr, N.; Karajeh, F. and El Quosy, D.A.H. (2014). Treated wastewater utilization for agricultural irrigation in Egypt, National conference on Water Quality: Challenges and Solutions, Conference: At National Research Centre- Cairo, Egypt., pp.: 35-46.

Elham, M.I. ; Mona, M.I.; Maather, M.E. and Heba, I.A. (2017). Studies on Pseudomonas Septicemia in Some Tilapia in Ismailia. SCVMJ., 12 (1): 107- 117.

Elmer, W. K.; Stephen, D. A.; William, M. J.; Paul, C. S. and Washington, C. W. Jr. (1998). Color Atlas and Textbook of Diagnostic Microbiology. 5th Ed. Lippincott. Philadelphia. New York.

Erova, T. E.; Kosykh, V. G.; Sha, J. and Chopra, A. K. (2012). DNA adenine methyltransferase (Dam) controls the expression of the cytotoxic enterotoxin (act) gene of Aeromonas hydrophila via tRNA modifying enzyme-glucose-inhibited division protein (GidA). Gene., 498: 280-287.

Hassan, M. A.; Noureldin, E.A.; Mahmoud A. M.; Fita N. A. (2017). Molecular identification and epizootiology of Aeromonas veronii infection among farmed Oreochromis niloticus in Eastern Province, KSA. Egyptian Journal of Aquatic Research 43 (2017) 161-167.

Hemmat, M. I.; Reham, A. A.; Nesreen, Z. E. and Hanan, R.M. G. (2018). Vibrio Species in Fish and Shell Fish. Benha Veterinary Medical Journal., 34(2): 246-254.

Holt, J.G.; Krieg, N.R.; Sueath, P.H.A.; Satley, J.T. and Williams, S.T. (1993). Bergey's manual of determinative bacteriology. 9th ed. Baltimore: Williams and Wilkins

Iglewski, B.H.; Liu, P.V. and Kabat, D. (1977). Mechanism of action of Pseudomonas aeruginosa exotoxin Aiadenosine diphosphate-ribosylation of mammalian elongation factor 2 in vitro and in vivo. Infection and immunity., 15 (1): 138-144.

Jones, M.K. and Oliver, J.D. (2009). Vibrio vulnificus: Disease and pathogenesis. Infect. Immun., 77:1723-1733.

Magdy, I.H.; Maha, A. E.; Hanaa, A. A.; Saher, A.E. and Amany, M. K. (2014). A contribution on Pseudomonas aeruginosa infection in African Catfish (Clarias gariepinus). Research Journal of Pharmaceutical, Biological and Chemical Sciences., 5(5): 575-588. 
Manal I. El-Barbary and Ahmed M. Hal. (2016). Isolation and molecular characterization of some bacterial pathogens in El-Serw fish farm, Egypt. Egypt. J. Aquat. Biol. \& Fish., 20 (4): 115-127.

Mandal, S.; Mandal, M.; Pal, N.K. and Basu, P.S. (2002). R-factor in Proteus vulgaris from ulcerative disease of fish, Channa punctatus. Indian J Exp Biol., 40(5):614-6.

Minich, J.J.; Zhu, Q.; Xu, Z.Z.; Amir, A.; Ngochera, M.; Simwaka, M.; Allen, E.E.; Zidana, H. and Knight, R. (2018). Microbial effects of livestock manure fertilization on freshwater aquaculture ponds rearing tilapia (Oreochromis shiranus) and North African catfish (Clarias gariepinus).Microbiologyopen., 7(6):1-15

Pujalte, M. et al.,(2003): Virulence and Molecular Typing of Vibrio harveyi Strains Isolated from Cultured Dentex, Gilthead Seabream and European Seabass. Syst Appl Microbiol., 26(2): 284-292

Quinn, P.J.; Markey, B.K.; Carter, M.E.; Donnelly, W.J.C and Leonard, F.C.(2002). Bacterial colonization, tissue invasion and clinical disease. Chapter, 7 In: Veterinary Microbiology and Microbial Disease. Blackwell Science Ltd, Oxford.

Rabab, R. ; Saad, M. S.; Fatin, S. H.; Mohamed, A. H. and Maarouf A. A. (2019). Incidence of Enterobacteriaceae in some freshwater fishes. Benha Veterinary Medical Journal., 37 : 64-68.

Saad, M. S. ; Maha, M. S. and Hania, E.A. (2015). Incidence of Vibrio species in fish with special emphasis on the effect of heat treatments. benha veterinary medical journal., 29 (1):38-44.

Scarpellini, M.; Franzetti, L. and Galli, A. (2004). Development of PCR assay to identify Pseudomonas fluorescens and its biotype. FEMS Microbiol Lett., 236(2):257-60 Sumithra, T.G.; Reshma, K.J.; Anusree, V.N.; Sayooj, P.; Sharma, S.R.K.; Suja, G.; Amala, P.V.; Joseph, S.b. and Sanil, N.K. (2019). Pathological investigations of Vibrio vulnificus infection in Genetically Improved Farmed Tilapia (Oreochromis niloticus L.) cultured at a floating cage farm of India. Aquaculture., 511: 1-11.

Wamala, S. P.; Mugimba, K. K.; Mutoloki, S.; Evensen, Ø.; Mdegela, R.; Byarugaba, D. K. and Sørum, H. (2018). Occurrence and antibiotic susceptibility of fish bacteria isolated from Oreochromis niloticus (Nile tilapia) and Clarias gariepinus (African catfish) in Uganda. Fisheries and Aquatic Sciences., 21(6):1-10

Younes, A.M.; Fares, M.O.; Gaafar, A.Y. and Laila, A. M. (2016). Isolation of Vibrio alginolyticus and Vibrio vulnificus Strains from Cultured Oreochromis niloticus Around Qarun Lake, Egypt. Global Veterinaria., 16 (1): 1-5.

Younes, A.M.; Laila, A. M.; Eida, M.F., and Gaafar, A.Y. (2015). Characterization and Pathogen Challenge of Pseudomonas Species from Oreochromis niloticus in Egypt. Research Journal of Pharmaceutical, Biological and Chemical Sciences., 6(1):312- 317.

Zhang, D.; Moreira, G.S.A.; Shoemaker, C.; Newton, J.C. and Xu, D.-H. (2016). Detection and quantification of virulent Aeromonas hydrophila in channel catfish tissues following waterborne challenge. FEMS Microbiol. Lett., 363. 